\title{
Ortaokul Öğrencilerinin Problem Kurmaya Yönelik Beceri ve Öz Yeterlik İnançlarının İncelenmesi*
}

\section{Kemal ÖZGEN ** Baran BAYRAM***}

Öz: Bu araştırmanın amacı ortaokul öğrencilerinin problem kurmaya yönelik becerilerini ve öz yeterlik inançlarını incelemektir. Araştırmada katılımcıların problem kurma becerileri ve öz yeterlik inançlarının; cinsiyet, sınıf seviyesi ve akademik başarı gibi bazı değişkenlere göre anlamlı farklılık gösterip göstermediği de incelenmiştir. Araştırma betimsel tarama yöntemi ile gerçekleştirilmiştir. Çalışmanın katılımcıları 346 ortaokul öğrencisidir. Verilerin toplanması için problem kurma testi ve problem kurma öz yeterlik ölçeği kullanılmıştır. Analizler sonucunda katılımcıların problem kurma becerilerinin iyi düzeyde olduğu ve problem kurmaya yönelik öz yeterlik inançlarının ise yüksek olduğu belirlenmiştir. Katılımcıların problem kurma becerileri cinsiyet ve sinıf seviyesine göre farklılık göstermezken, akademik başarıya göre anlamlı farklılık göstermiştir. Katılımcıların problem kurmaya yönelik öz yeterlikler inançları cinsiyete göre anlamlı farklılık göstermezken, sınıf seviyesi ve akademik başarı değişkenlerine göre anlamlı farklılık göstermektedir. Ayrıca katılımcıların problem kurmaya yönelik öz yeterlik inançlarının problem kurma becerilerinin anlamlı bir yordayıcısı olduğu belirlenmiştir.

Anahtar Kelimeler: Ortaokul öğrencileri, Örüntü, Öz yeterlik, Problem kurma.

\section{Investigation of Middle School Students' Problem Posing Skills and Problem Posing Self-Efficacy Beliefs}

Abstract: The aim of this study was to examine the skills and self-efficacy beliefs of middle school students in problem posing. It was also aimed to determine the relationship between

\footnotetext{
* Bu çalışma birinci yazarın danışmanlığında ikinci yazar tarafindan yapılan yüksek lisans tezinden hazırlanmıştır.

Dicle Üniversitesi Bilimsel Araştırma Projeleri Koordinasyon Birimi Koordinatörlüğü'nce desteklenmiştir. Proje Numarası: ZGEF.18.021, Y11: 2018.

** Doç. Dr., Dicle Üniversitesi Ziya Gökalp Eğitim Fakültesi Matematik ve Fen Bilimleri Eğitimi Bölümü Matematik Eğitimi Anabilim Dal1, ORCID: 0000-0002-7015-6452, ozgenkemal@gmail.com

*** Öğretmen, Milli Eğitim Bakanlığı, ORCID: 0000-0001-6720-0638, baranbayramm@gmail.com
} 
problem-posing skills and problem-posing self-efficacy beliefs. In addition, it was investigated whether the participants' problem-posing skills and self-efficacy beliefs differ significantly according to some independent variables such as gender, grade levels and academic achievement. The research was conducted with descriptive survey method. The participants of the study were 346 middle school students. Problem-posing test and problem posing selfefficacy scale were used to collect data. As a result of the analysis, it was determined that the problem-posing skills of the participants were good level and the self-efficacy beliefs about problem-posing were high level. While the problem-posing skills of the participants did not differ according to their gender and grade level, significant differences were found according to their academic achievement. There was not a significant difference between the self-efficacy beliefs of the participants about problem-posing according to the gender, but there was a significant difference according to the grade level and academic achievement. In addition, it was determined that the self-efficacy beliefs of the participants about problem-posing were a significant predictor of the problem-posing skills.

Keywords: Middle school students, Pattern, Problem-posing, Self-efficacy.

\section{Giriş}

Son yıllarda eğitim konusundaki görüş ve yaklaşımlar çağa ayak uyduracak şekilde güncellenmektedir ve yenilenmektedir. Dijitalleşen dünyada matematiksel bilgi, beceri ve eğilimlerin önemi ise gittikçe artmaktadır (Grootenboer \& Marshman, 2016). Bu bitmek bilmeyen yenilenme sürecinde sürekli yeni bakış açıları ve kavramlar ortaya çıksa da bazı temel becerilerin gerekliliği geçerliğini korumaktadır. Matematik eğitimi bağlamında, problem çözme, problem kurma ve matematiğe yönelik duyuşsal beceriler bu temel beceriler arasındadır (Milli Eğitim Bakanlı̆̆g [MEB], 2018).

Problem çözme kişinin zihnini zorlayan ve genişleten bir dizi etkinlik olarak tanımlanmaktadır (English \& Sriraman, 2010). Silver (1987) problem çözme sürecini örüntü bulma, temsiller, anlama, zihin şemaları ve üst bilişsel süreçler olmak üzere 5 tema ile açıklamaktadır. Polya'ya (1973) göre problem çözme pratik becerilere benzer ve 4 aşamada gerçekleştirilebilir. Bu aşamalar; problemi anlama, çözüm için plan yapma, çözüm planını uygulama ve değerlendirme şeklindedir. Polya'nın bu yaklaşımı matematik otoriteleri tarafından genel geçer görüş olarak kabul görmektedir. Kilpatrick’e (1987) göre problem, problemi çözen kişi tarafından yeniden formüle edilerek çözülebilir. Bir başka deyişle 
problemler çözülürken başka problemler için çıkış noktası olmaktadır. Bu doğrultuda Gonzales (1998), Polya tarafindan öne sürülen problem çözme basamaklarına beşinci basamak olarak problem kurmayı eklemektedir. Ülkemizde kullanılmakta olan matematik öğretim programında öğrencilerin problem çözme becerilerinin geliştirilmesi için; problem durumunu anlama, çözüm için plan geliştirme, geliştirilen planı uygulama, çözümün değerlendirilmesi, çözümü genelleme, benzer ve özgün problemler kurma süreçlerinin gözetilmesi vurgulanmaktadır (MEB, 2013; 2018).

Problem kurma, kişinin karşılaştığı durumları geçmiş öğrenmeleri ve kazandığı matematiksel beceriler gibi matematiksel tecrübelerinin temelinde yorumlaması ve bu yorumları somut matematiksel problemler şeklinde ifade etmesi olarak tanımlanmaktadır (Stoyanova \& Ellerton, 1996). Problem kurma etkinliklerinin öğrencilerin sorgulama, yorumlama (Akay, Soybaş \& Argün, 2006, Brown \& Walter, 2005) ve eleştirel düşünme becerilerini geliştirdiği belirtilmektedir (Nixon-Ponder, 1995). Problem kurma süreçlerinde öğrencilerin matematik dersine yönelik kaygılarının azalması (Brown \& Walter, 2005) ve kavram yanılgılarının tespit edilebilmesi (Tichá \& Hospesova, 2009; Toluk-Uçar, 2009) matematik eğitimi açısından çok önemlidir. $\mathrm{Bu}$ doğrultuda problem kurma etkinlikleri öğrencilerin matematiksel anlamaları ve duyuşsal becerileri hakkında fikir vermesi bakımından bir değerlendirme aracı olarak kullanılabilir (English, 1998; Toluk-Uçar, 2009). Problem çözme becerileri matematiksel düşünmenin ve öğrenmenin ayrılmaz bir parçası ve matematik öğretiminin temel amaçlarındandır (MEB, 2013; NCTM, 2000). Öğrencilerin problem kurma becerileri, problem çözme becerileri ile yakından ilişkilidir (Cai, 1998; Christou, Mousoulides, Pittalis, Pitta-Pantazi \& Sriraman, 2005; Ellerton, 1986; Kilpatrick, 1987; Silver \& Cai, 1996; Toluk-Uçar, 2009). Yapılan çalışmalar problem kurma etkinliklerinin öğrencilerin problem çözme becerilerinin gelişmesine yardımcı olduğunu göstermektedir (Cai, Moyer, Wang, Hwang, Nie \& Garber, 2013; English, 1997). Problem kurma etkinliklerinin bir diğer avantaj1, açık uçlu etkinlikler olmaları sayesinde günlük yaşam durumları ile ilişkilendirilebilmeleridir (Kovacs, 2017). Matematik derslerinde kavramların günlük yaşamla ilişkilendirilmesi öğrencilerin matematiksel anlamalarını güçlendirir (Baki, 2015). Bu ilişkilendirmeler sınıfta problem kurma gibi açık uçlu etkinlikler ile daha etkili ve verimli olabilmektedir (Kovacs, 2017). Bu durumda problem kurma etkinliklerinin matematik eğitiminde hem amaç hem de bir araç olarak kullanılmasının gerekliliği ortaya çıkmaktadır (Kilpatrick, 1987).

Matematik eğitiminde, problem çözme ve problem kurma becerileri gibi öğrencilerin sahip olması gereken bir diğer önemli temel beceri duyuşsal becerilerdir. Duyuşsal beceriler 
öğrencilerin matematiğe verdikleri önem, matematiğin faydalarının farkında olma, matematik yapabileceğine inanma gibi tutum ve inançlara dayalıdır. Öğrencilerin matematiğe yönelik olumlu tutum ve inançlar geliştirmeleri, öz güven sahibi olmaları matematik eğitiminin önceliklerinden olmalıdır (Hekimoğlu \& Kittrell, 2010; MEB, 2013). MEB (2013: s.6) tarafından hazırlanan ortaokul matematik dersi öğretim programında "matematikte özgüven duyma ve matematiği yapabileceğine inanma" ifadesi yer almaktadır. Bu ifade öğrencilerin güçlü öz yeterlik inançlarına sahip olmaları gerektiğine işaret etmektedir. Öz yeterlik inancı, belirli bir amaca ulaşmak için gerekli etkinlikleri, süreçleri başarılı bir şekilde düzenleyebilme ve yürütebilmeye yönelik kişisel inançtır (Bandura, 1986). Öz yeterlik inançları kişinin davranış seçimlerinde ve zorlayıcı durumlar karşısında gösterdiği performans ve sürekliliği üzerinde büyük ölçüde etkilidir (Bandura, 1977; Zimmerman, 2000). Yapılan araştırmalar öz yeterlik inançlarının öğrencilerin genel akademik başarıları, matematik başarıları ve problem çözme becerileri ile ilişkili olduğunu ortaya koymaktadır (Hoffman, 2010; Matsui, Matsui \& Ohnishi, 1990; Pajares, 1996). Böyle önemli bir ilişki olmasına rağmen ilgili literatürde öğrencilerin problem kurmaya yönelik öz yeterlikleri ile ilgili sınırlı sayıda çalışma bulunmaktadır. Oysa yapılan çalışmalar öğrencilerin öz yeterlik inançları problem kurma becerilerinin kuvvetli bir belirleyicisi olduğu sonucunu ortaya koymaktadır (Nicolau \& Philippou, 2007). Bu doğrultuda öğrencilerin problem kurmaya yönelik öz yeterliklerini belirlemeye yönelik çalışmaların problem kurma konusundaki cevaplanmamış bazı sorulara 1ş1k tutacağı düşünülmektedir.

Öğrencilerin matematiksel becerileri ve duyuşsal becerileri üzerinde etkili olduğu düşünülen bazı değişkenler mevcuttur. Öğrencilerin cinsiyetleri, sınıf seviyeleri, akademik başarıları bu değişkenlerden bazılarıdır (Weissglass, 2002). Ortaokul öğrencilerinin cinsiyetlerinin matematiksel beceriler ve duyuşsal becerileri üzerindeki etkilerinin incelendiği çalışmaların sonuçları değişkenlik göstermektedir (Akkan, Çakıroğlu \& Güven, 2009; Özgen, Aydın, Geçici \& Bayram, 2017; Semizoğlu, 2013). Bu çalışmalar problem kurma bağlamında incelendiğinde erkek öğrencilerin kız öğrencilere göre daha başarılı olduğu çalışmaların (Akkan, Çakıroğlu \& Güven, 2009) yanı sıra kız öğrencilerin erkek öğrencilere göre daha başarılı olduğu çalışmaların da (Semizoğlu, 2013) olduğu görülmektedir. Ayrıca cinsiyetin problem kurma becerileri üzerinde etkisinin olmadığının belirtildiği çalışmalar da (Özgen, Aydın, Geçici \& Bayram, 2017) mevcuttur.

Ortaokul öğrencilerinin matematiksel becerileri üzerinde etkili olabilecek bir diğer değişken sınıf seviyeleridir. Farklı sınıf seviyelerindeki öğrencilerin matematiksel ve duyuşsal 
becerilerinin incelendiği çalışmalarda farklı sonuçların elde edildiği görülmektedir (Arıkan \& Ünal, 2015; Cai, 2003; Katrancı \& Şengül, 2019).

Bir öğrencinin akademik başarı seviyesi ile matematiksel ve duyuşsal becerileri arasında doğrudan bir ilişki olduğu düşünülmektedir. Problem kurma ve akademik başarı arasındaki ilişkiyi inceleyen birçok çalışma, akademik açıdan başarılı öğrencilerin başarısız öğrencilere göre daha yüksek problem kurma becerilerine sahip olduklarını göstermektedir (Ellerton, 1986; Özgen \& diğ., 2017; Yuan \& Sriraman, 2011).

Matematik eğitimi ile ilgili yapılan araştırmalarda sıkça vurgulansa da problem kurma süreçleri ile ilgili bilinenler çok azdır (Kilpatrick, 1987). Yapılan araştırmalar problem kurma ile problem çözme becerilerinin birbirini tamamladığını göstermektedir (Cai, 1998; Ellerton, 1986; Silver \& Cai, 1996). Problem kurma etkinlikleri öğrencilerin problem çözme süreçleri, öğrencilerin bilişsel süreçleri, matematiksel anlamaları ve kavram yanılgıları hakkında değerli bilgilerin elde edilebileceği etkinliklerdir (Cai, 1998; Leung, 2013; Silver, 1994; Tichá \& Hospesova, 2009; Toluk-Uçar, 2009). Birçok araştırmada öğrencilerin ve öğretmenlerin problem kurmada zorlandıkları belirtilmiştir (Cai \& Hwang; 2002; Ellerton, 1986; English, 1998; Özgen \& diğ., 2017; Silver, Mamona-Downs, Leung \& Kenney, 1996). Bu doğrultuda ortaokul öğrencilerinin problem kurma becerilerinin incelenmesinin bu konudaki eksiklikleri ve soru işaretlerini gidereceği düşünülmektedir.

Duyuşsal beceriler öğrencilerin kazanması gereken temel becerilerdendir (MEB, 2013). Bu duyuşsal becerilerden biri öğrencilerin öz yeterlik inançlarıdır. Bandura'ya (1986) göre kişinin öz yeterlik inançları akademik süreçlerdeki başarısını etkilemektedir. Öz yeterlik inançları bireyin matematiğe yönelik tutumları, matematik başarısı (Ayotola \& Adedeji, 2009; Hackett \& Betz, 1989; Pajares, 1996), problem çözme becerisi (Pajares \& Miller, 1994; Pajares \& Graham, 1999), problem kurma becerisi (Nicolau \& Philippou, 2007), matematik kaygıs1 (Bandura, 1997; Hoffman, 2010) üzerinde etkilidir. Bu çalışma ortaokul öğrencilerinin problem kurmaya yönelik öz yeterliklerini ve cinsiyet, sınıf seviyesi, akademik başarı gibi bağımsız değişkenlerin öz yeterlik inançları üzerindeki etkisini belirlemeyi amaçlamaktadır.

$\mathrm{Bu}$ çalışmada ortaokul öğrencilerinin örüntüler konusuna yönelik problem kurma becerilerinin ve problem kurmaya yönelik öz yeterlik inançlarının belirlenmesi amaçlanmıştır. Ayrıca ortaokul öğrencilerinin problem kurma becerileri ile problem kurmaya yönelik öz yeterlik inançları arasındaki ilişkide incelenmiştir. Öğrencilerin cinsiyetleri, akademik başarıları, sınıf seviyeleri gibi bazı değişkenlerin problem kurma becerileri ve öz yeterlik 
inançları üzerindeki etkilerinin belirlenmesi çalışmanın diğer amaçlarındandır. Bu doğrultuda çalışmanın alt problemleri aşağıdaki gibi belirlenmiştir:

1) Ortaokul öğrencilerinin örüntüler konusuna yönelik farklı problem kurma durumlarındaki becerileri nasıldır?

2) Ortaokul öğrencilerinin örüntüler konusuna yönelik problem kurma becerileri; öğrencilerin cinsiyetleri, sınıf seviyeleri ve matematik akademik başarılarına göre anlamlı bir şekilde farklılaşmakta mıdır?

3) Ortaokul öğrencilerinin problem kurmaya yönelik öz yeterlik inançları nasıldır?

4) Ortaokul öğrencilerinin problem kurmaya yönelik öz yeterlik inançları; öğrencilerin cinsiyetleri, sınıf seviyeleri ve matematik akademik başarılarına göre anlamlı bir şekilde farklılaşmakta mıdır?

5) Ortaokul öğrencilerinin problem kurma becerileri ile problem kurmaya yönelik öz yeterlik inançları arasında anlamlı bir ilişki var mıdır?

\section{Yöntem}

\section{Araştırmanın Deseni}

$\mathrm{Bu}$ çalışmada ortaokul öğrencilerinin problem kurma becerileri ve problem kurmaya yönelik öz yeterliklerinin incelenmesi amaçlanmıştır. Çalışma tarama metodu ile gerçekleştirilmiş bir betimsel çalışmadır. Tarama yöntemi ile mevcut durum detaylı bir şekilde betimlenebilmekte ve incelenebilmektedir (Ruane, 2005). Çalışmada ortaokul öğrencilerinin problem kurma becerileri ve problem kurmaya yönelik öz yeterlik inançları ile ilgili durumları ayrıntılı bir şekilde incelenmek istendiğinden tarama yöntemi uygun görülmüştür. Ayrıca örneklem sayısının nispeten büyük olması da tarama yöntemini gerekli kılmaktadır.

\section{Çalışma Grubu}

Bu çalışma Türkiye'nin güneydoğu bölgesindeki bir büyükşehrin şehir merkezinde yer alan 4 farklı okulda öğrenim görmekte olan 346 ortaokul öğrencisi ile gerçekleştirilmiştir. Araştırmanın çalışma grubu 2017-2018 eğitim öğretim yılında 6., 7. ve 8. sınıfta öğrenim görmekte olan ortaokul öğrencilerinden oluşmaktadır. Çalışmanın yapıldığı eğitim öğretim yılında uygulanan matematik dersi öğretim programına göre aritmetik diziler konusu 6. sınıfta sunulmaktadır. Bu sebeple 5. sınıflar problem kurma etkinlikleri için gerekli kazanımların tümüne sahip olmadıkları için çalışmaya dahil edilmemişlerdir. Bu doğrultuda katılımcılar 
basit seçkisiz örneklem yöntemiyle seçilmiştir. Bu örneklem yönteminin seçilmesindeki amaç katılımcıların olabildiğince evreni temsil yeteneğine sahip olmasıdır. Basit seçkisiz örnekleme yönteminde katılımcılar belirli özellikleri taşıyan kişiler arasından rasgele seçilir (Teddlie \& Yu, 2007). Çalışmaya katılan 346 öğrencinin, 193’ü kı, 153’ü ise erkektir. Katılımciların 114'ü 6. sınıf, 110'u 7. sınıf, 122'si ise 8. sinıf öğrencisidir.

\section{Veri Toplama Araçları}

Yapılan araştırmada gerekli verilerin toplanması için Problem Kurma Testi, Problem Kurma Öz Yeterlik Ölçeği olmak üzere iki veri toplama aracı kullanılmıştır.

Katılımcıların problem kurma becerilerini belirlemek amacıyla araştırmacı tarafından geliştirilen Problem Kurma Testleri kullanılmıştır. Problem Kurma Testi her biri serbest, yarıyapılandırılmış ve yapılandırılmış problem kurma durumlarından oluşan her biri 3 maddelik iki ayrı testten oluşmaktadır. Testlerde yer alan problem kurma etkinlikleri ortaokul beşinci ve altıncı sınıf öğretim programı cebir öğrenme alanında yer alan cebirsel ifadeler alt öğrenme alanı ile sayılar ve işlemler öğrenme alanında yer alan doğal sayılar alt öğrenme alanlarına yönelik hazırlanmıştır. Problem Kurma Testi hazırlanırken matematik eğitimi alanında uzman üç akademisyen ve öğretmenlerden görüş alınmıştır. Problem Kurma Testinin geçerliğinin sağlanması için farklı bir örneklem ile pilot uygulama yapılmıştır. Pilot uygulamadan elde edilen geri dönütler doğrultusunda gerekli düzeltmeler ve değişiklikler yapılmıştır. $\mathrm{Bu}$ doğrultuda etkinliklerin daha anlaşılır olması için testlere yönergeler eklenmiş ve yazım, anlatım açısından kontroller yapılmıştır. Problem kurma testlerinin giriş kısımlarında problem kurma yönergelerine yer verilmiştir. Kullanılan problem kurma testlerinin güvenirliği hesaplanmış ve cronbach-alfa güvenirlik katsayısı 0.93 olarak belirlenmiştir.

Şekil 1'deki problem kurma etkinliği birinci problem kurma testinde yer alan yapılandırılmış bir problem kurma etkinliğine örnektir. Bu problem aracılığıyla yapılan etkinlikte mevcut bir problemin varsayım ve koşullarının değiştirilmesiyle yeni bir problem geliştirilmesi istendiğinden yapılandırılmış problem kurma durumuna bir örnektir. Ayrıca bu etkinlikte katılımcıların 6. sınıf seviyesinde edinmiş oldukları artan örüntü ile ilgili kazanıma yönelik bir durum mevcuttur.

“Evinin penceresinden caddedeki trafiği izleyen Ali her bir kırmızı ışıkta duran araç sayısının bir önceki ışıkta duran araç sayısından 3 fazla olduğunu fark ediyor. Buna göre ilk kırmızı ışıkta 7 araç durmuşsa, 10. kırmızı ışııta kaç araç duracaktır?

Yukarıdaki probleme benzer bir problem kurunuz ve kurduğunuz problemi cözünüz.”

Şekil 1. Problem Kurma Testi 1'de yer alan yapılandırılmış problem kurma etkinliği örneği 
Şekil 2'de yer alan etkinlik ikinci problem kurma testinde yer alan yarı-yapılandırılmış bir problem kurma etkinliğine örnektir. Bu etkinlikte katılımcılardan verilen açık bir durumu tamamlayarak problem kurmaları istenmektedir. Etkinlikte artan şekil örüntüsü içeren bir durum kullanılmıştır.

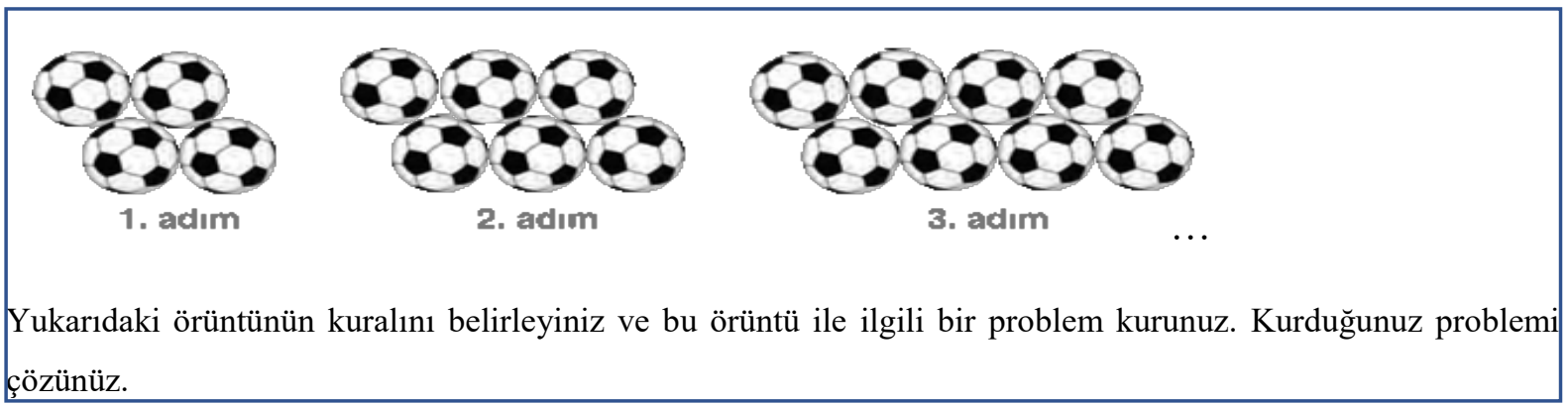

Şekil 2. Problem Kurma Testi 2'de yer alan yarı-yapılandırılmış problem kurma etkinliği örneği

Katılımcıların problem kurmaya yönelik öz yeterliklerinin belirlenmesi amacıyla Özgen ve Bayram (2019) tarafından geliştirilen Problem Kurma Öz Yeterlik Ölçeği kullanılmıştır. İlgili ölçek 7'si olumsuz 17'si olumlu toplam 24 maddeden ve 5 alt faktörden oluşmaktadır. Problem Kurma Öz Yeterlik Ölçeği maddeleri 5'li likert tipinde bir ölçektir. Yüksek puanlar yüksek öz yeterlik inançlarına düşük puanlar ise düşük öz yeterlik inançlarına işaret etmektedir. İlgili ölçeğin Cronbach-alfa ölçüm güvenirlik katsayısı 0.85 tir. Bu çalışmada uygulanan ölçeğin güvenirlik katsayısı 0.88 olarak hesaplanmıştır.

Veri toplama süreci ilgili kazanımlar göz önüne alınarak eğitim-öğretim yılının 2. dönemi gerçekleştirilmiştir. Veri toplama araçları katılımcılara verilmiş ve problem kurma testlerindeki etkinlikleri cevaplamadan incelemeleri istenmiştir. Daha sonra problem kurma öz yeterlik ölçeğini cevaplamaları sağlanmıştır. Bu süreç yaklaşık 15 dakika zaman almıştır. Ölçeğin uygulanmasını takiben katılımcılardan problem kurma testlerini cevaplamaları istenmiştir. Tüm veri toplama süreci iki ders saati $(80 \mathrm{dk})$ sürmüştür.

\section{Verilerin Analizi}

Katılımcıların problem kurma testlerine verdikleri yanıtlar Özgen ve diğ. (2017) tarafından geliştirilen dereceli puanlama anahtarı (rubrik) kullanılarak değerlendirilmiştir. $\mathrm{Bu}$ rubrik (derecelendirilmiş puanlama anahtarı) problem kurma becerilerini 7 farklı kritere göre değerlendirmeye imkân sağlamaktadır. Bu kriterler matematik dilini kullanabilme, dil ve anlatım, kazanımlara uygunluk, veri miktarı ve niteliği, çözülebilirlik, özgünlük ve kurulan 
problemin öğrenci tarafından çözülme durumu kriterleridir. Her bir kriter için şartların sağlanma durumuna göre 4 ayrı düzey bulunmaktadır. Bu düzeyler; 1. düzey (0 puan), 2. düzey (1 puan), 3. düzey (2 puan) ve 4. düzey (3 puan) olarak sıralanmaktadır. Bir kriterin şartlarını tam karşılayan bir katılımcı bu kriterden 3 puan, şartları hiç karşılamayan katılımcı ise 0 puan almaktadır. Öğrencilerin problem kurma becerileri, rubrikte belirtilen yedi kriterden alınan toplam puan olarak değerlendirilmiştir. İlgili literatürde farklı becerilerden alınan puanların toplamı problem kurma becerisi olarak değerlendirilmektedir (Geçici \& Aydın, 2019; Özgen \& diğ., 2017).

Katılımcı cevaplarının puanlanması araştırmacılardan biri tarafından farklı tarihlerde iki defa gerçekleştirilmiştir ve puanlamanın güvenirliğinin belirlenmesi için puanlamalar arasındaki uyuma bakılmıştır. Her iki puanlama arasındaki uyum Miles ve Huberman (1994) tarafından kullanılan formül ile hesaplanmıştır. Bu formüle göre uyum her iki puanlamada aynı kodlanan veri sayısının toplam kodlama sayısına oranlanmasıyla hesaplanır. Bu hesaplamaya göre farklı tarihlerde yapılan iki kodlama arası uyum 0.83 olarak hesaplanmıştır. Farklı kodlamalar için nihai bir kontrolle sonuca varılmıştır.

Katılımciların problem kurma becerilerinin belirlenmesi amaciyla betimsel analizler yapılmıştır. Problem kurma becerileri ile bağımsız değişkenler arasındaki ilişki incelenmiş olup; katılımcıların problem kurma becerileri ile cinsiyetleri arasında bir ilişki olup olmadığ ilişkisiz örneklemler t-testi ile test edilmiştir. Katılımcıların problem kurma becerileri ile bağımsız değişkenler arasında ilişki olup olmadığının belirlenmesi için tek yönlü varyans analizi yapılmıştır.

Katılımcıların problem kurma becerileri ile problem kurmaya yönelik öz yeterlik inançları arasında anlamlı bir ilişki olup olmadığının belirlenmesi için basit regresyon analizi yapılmıştır. Son olarak problem kurma ve öz yeterlik toplam puanlarındaki değişim miktarlarını hesaplamak için etki değerleri hesaplanmıştır.

Katılımcıların Problem Kurma Öz Yeterlik Ölçeğine verdiği cevaplar; "kesinlikle katıliyorum" 5 puan, "katıliyorum" 4 puan, "karasızım" 3 puan, "katılmıyorum" 2 puan ve "kesinlikle katılmıyorum" 1 puan olacak şekilde puanlanmıştır. Katılımcıların öz yeterlik inançları ile cinsiyetleri arasında anlamlı ilişki olup olmadığı ilişkisiz örneklemler t-testi ile test edilmiştir. Öz yeterlik inançları ile sınıf seviyeleri, akademik başarı gibi bağımsız değişkenler arasında ilişki olup olmadığının belirlenmesi amacıyla tek yönlü varyans analizi yapılmıştır. 


\section{Bulgular}

Verilerin analizi sonucunda katılımcıların problem kurma testi puanlarının aritmetik ortalaması $\overline{\mathrm{X}}=84.28$ olarak hesaplanmıştır. Araştırmaya katılan ortaokul öğrencilerinin problem kurma becerilerinin iyi seviyede olduğu görülmektedir.

Tablo 1. Problem kurma testi puanları ile ilgili betimsel istatistiksel bilgiler

\begin{tabular}{cccccc}
\hline Sinıf & n & Min. & Max. & $\overline{\mathbf{X}}$ & SS \\
\hline 6. sinif & 114 & 5.00 & 121.00 & 85.41 & 23.06 \\
7. sinif & 110 & 12.00 & 119.00 & 80.20 & 22.88 \\
8. sinif & 122 & 36.00 & 123.00 & 86.91 & 21.81 \\
Toplam & 346 & 5.00 & 123.00 & 84.28 & 22.68 \\
\hline
\end{tabular}

Sınıf seviyelerine göre problem kurma testi ortalama puanlarına bakıldığında; problem kurma testinden aldıkları puan ortalamaları birbirine yakın olsa da 7. sınıf öğrencilerinin problem kurma testinde 6 . ve 8. sınıf öğrencilerine göre daha başarısız olduğu görülmektedir. 8. sınıf öğrencilerinin problem kurma testinde 6. ve 7. sınıf öğrencilerine göre daha başarılı oldukları elde edilen bir diğer bulgudur.

\section{Birinci Alt Probleme Yönelik Bulgular}

Ortaokul öğrencilerinin farklı problem kurma durumlarındaki becerilerini belirlemek için problem kurma testindeki aldıkları puanlara bakılmıştır.

Tablo 2. Katılımcıların farklı problem kurma durumlarındaki becerileri ile ilgili istatistikler

\begin{tabular}{llccccc}
\hline Sınıf & Problem Kurma & $\mathbf{n}$ & Min. & Max. & $\overline{\mathbf{X}}$ & SS \\
\hline \multirow{3}{*}{ 6. sinıf } & Serbest & 114 & 3.00 & 41.00 & 31.29 & 8.99 \\
& Yar1-yapıllandırılmış & 114 & .00 & 40.00 & 28.30 & 9.64 \\
& Yapılandırılmış & 114 & .00 & 41.00 & 25.80 & 10.78 \\
\hline \multirow{3}{*}{ 7. sinıf } & Serbest & 110 & 1.00 & 42.00 & 28.59 & 10.14 \\
& Yarı-yapılandırılmış & 110 & 4.00 & 40.00 & 27.15 & 8.09 \\
& Yapılandırılmış & 110 & .00 & 41.00 & 24.45 & 10.31 \\
\hline \multirow{3}{*}{ 8. sinıf } & Serbest & 122 & .00 & 42.00 & 29.99 & 9.40 \\
& Yar1-yapilandırılmış & 122 & .00 & 41.00 & 28.97 & 10.43 \\
& Yapılandırılmış & 122 & .00 & 42.00 & 27.95 & 10.35 \\
\hline \multirow{3}{*}{ Toplam } & Serbest & 346 & .00 & 42.00 & 29.97 & 9.55 \\
& Yar1-yapılandırılmış & 346 & .00 & 41.00 & 28.17 & 9.48 \\
& Yapılandırılmış & 346 & .00 & 42.00 & 26.13 & 10.55 \\
\hline
\end{tabular}

Tablo 2 incelendiğinde ortaokul öğrencilerinin farklı problem kurma durumlarında aldıkları puanların ortalamaları birbirine yakın sayılmakla birlikte katılımcıların en iyi sonuçları serbest problem kurma durumlarında en düşük sonuçları ise yapılandırılmış problem kurma durumlarında aldıkları görülmektedir. Bu durum tüm sınıf seviyelerindeki katılımcılar için aynıdır. Bunun yanı sıra serbest problem kurma durumlarında 6. sınıf öğrencileri daha 
başarılı iken yarı yapılandırılmış ve yapılandırılmış problem kurma durumlarından 8. sınıf öğrencilerinin daha başarılı oldukları görülmektedir.

Tablo 3. Problem kurma puanlarının ilişkili örneklemler için tek faktörlü ANOVA sonuçları

\begin{tabular}{ccccccc}
\hline Varyansın Kaynağı & Kar. Top. & Sd & Kar. Ort. & F & p & $\begin{array}{c}\text { Anlaml } \\
\text { Fark }\end{array}$ \\
\hline Denekler arası & 59195.55 & 345 & 171.58 & & & S-YY, S-Y, \\
Ölçüm & 2559.61 & 2 & 1279.80 & 21.159 & $.00 *$ & YY-Y \\
Hata & 41734.38 & 690 & 60.48 & & & \\
Toplam & 103489.54 & 1037 & & & & \\
\hline
\end{tabular}

( $\mathrm{S}=$ serbest problem kurma, YY=yarı-yapılandırılmış problem kurma, $\mathrm{Y}=$ yapılandırılmış problem kurma)

Analiz sonuçlarına göre katılımcıların serbest, yarı-yapılandırılmış ve yapılandırılmış problem kurma puanları arasında istatistiksel olarak anlamlı bir farklılık bulunmuştur $[F(2,690)=21,159, \mathrm{p}<.05]$. Anlamlı farklılığın serbest problem kurma etkinliklerinden elde edilen puanlar ile yarı-yapılandırılmış ve yapılandırılmış problem kurma durumlarından elde edilen puanlar arasında, serbest problem kurma etkinlikleri lehine ortaya çıtığı görülmüştür. Ayrıca yarı-yapılandırılmış problem kurma durumları ile yapılandırılmış problem kurma durumları arasında yarı-yapılandırılmış problem kurma durumları lehine anlamlı farklılık görülmüştür. $\mathrm{Bu}$ doğrultuda katılımcıların serbest problem kurma durumlarında yarı yapılandırılmış ve yapılandırılmış problem kurma durumlarına göre daha başarılı oldukları söylenebilir.

\section{İkinci Alt Probleme Yönelik Bulgular}

$\mathrm{Bu}$ problemi cevaplamak için katılımcıların problem kurma becerilerinin bazı değişkenler ile anlamlı bir şekilde ilişkili olup olmadığı araştırılmıştır.

Tablo 4. Katılımcıların problem kurma testi puanlarının cinsiyete göre t-testi sonuçları

\begin{tabular}{ccccccc}
\hline Cinsiyet & $\mathbf{n}$ & $\overline{\mathbf{X}}$ & SS & sd & t & p \\
\hline Erkek & 153 & 83.27 & 22.35 & 344 & .738 & .461 \\
Kiz & 193 & 85.08 & 22.97 & & & \\
\hline
\end{tabular}

Yapılan ilişkisiz örneklemler t-testi sonuçlarına göre katılımcıların problem kurma testinden aldıkları puanlar cinsiyetlerine göre anlamlı farklılık göstermemektedir, $\mathrm{t}$ (344) $=0.738, \mathrm{p}>.05$. Her ne kadar kız öğrencilerin problem kurma testi ortalama puanları $(\overline{\mathrm{X}}=85.08)$, erkek öğrencilerin problem kurma testi ortalama puanlarından $(\overline{\mathrm{X}}=83.27)$ fazla olsa da t-testi sonuçları bu farkın katılımcıların cinsiyetlerinden kaynaklanmadığını göstermektedir. $\mathrm{Bu}$ doğrultuda öğrencilerin cinsiyetleri ile problem kurma başarı puanları arasında anlamlı bir ilişki olmadığı yorumu yapılabilir. 
Ortaokul öğrencilerinin problem kurma testinden aldıkları puanların, sınıf seviyelerine göre anlamlı bir farklılık gösterip göstermediğini belirlemek için ilişkisiz örneklemler tek yönlü varyans analizi testi yapılmıştır. Bu doğrultuda farklı sınıf seviyelerinde yer alan katılımcılara grup ismi verilmiştir.

Tablo 5. Problem Kurma Testinden alınan puanlara ait betimsel istatistikler

\begin{tabular}{llccccc}
\hline Sınıf & \multicolumn{1}{c}{ Problem Kurma } & $\mathbf{n}$ & Min. & Max. & $\overline{\mathbf{X}}$ & SS \\
\hline \multirow{3}{*}{ 6. sınıf(A) } & Serbest & 114 & 3.00 & 41.00 & 31.29 & 8.99 \\
& Yar1-yapılandırılmış & 114 & .00 & 40.00 & 28.30 & 9.64 \\
& Yapılandırılmış & 114 & .00 & 41.00 & 25.80 & 10.78 \\
\hline \multirow{3}{*}{ 7. sinıf (B) } & Serbest & 110 & 1.00 & 42.00 & 28.59 & 10.14 \\
& Yar1-yapılandırılmış & 110 & 4.00 & 40.00 & 27.15 & 8.09 \\
& Yapılandırılmış & 110 & .00 & 41.00 & 24.45 & 10.31 \\
\hline \multirow{3}{*}{ 8. sınıf (C) } & Serbest & 122 & .00 & 42.00 & 29.99 & 9.40 \\
& Yar1-yapılandırılmış & 122 & .00 & 41.00 & 28.97 & 10.43 \\
& Yapılandırılmış & 122 & .00 & 42.00 & 27.95 & 10.35 \\
\hline \multirow{3}{*}{ Toplam } & Serbest & 346 & .00 & 42.00 & 29.97 & 9.55 \\
& Yar1-yapılandırılmış & 346 & .00 & 41.00 & 28.17 & 9.48 \\
& Yapılandırılmış & 346 & .00 & 42.00 & 26.13 & 10.55 \\
\hline
\end{tabular}

Tablo 5 incelendiğinde serbest problem kurma durumlarından en yüksek ortalama puanları altıncı sınıfların, yarı yapılandırılmış ve yapılandırılmış problem kurma durumlarında en yüksek ortalama puanları ise sekizinci sınıfların aldığı görülmektedir.

Tablo 6. Problem kurma testi puanlarının sınıf seviyelerine göre ANOVA sonuçları

\begin{tabular}{|c|c|c|c|c|c|c|c|}
\hline Problem Kurma & $\begin{array}{c}\text { Varyansın } \\
\text { Kaynağı }\end{array}$ & Kar. top. & Sd & Kar. ort. & $\mathbf{F}$ & $\mathbf{p}$ & $\begin{array}{c}\text { Anlamlı } \\
\text { Fark }\end{array}$ \\
\hline \multirow{3}{*}{ Serbest } & Gruplar arası & 410.373 & 2 & 205.186 & 2.266 & .105 & \\
\hline & Gruplar içi & 31063.442 & 343 & 90.564 & & & \\
\hline & Toplam & 31473.815 & 345 & & & & \\
\hline \multirow{3}{*}{$\begin{array}{c}\text { Yarı- } \\
\text { yapılandırılmış }\end{array}$} & Gruplar arası & 194.692 & 2 & 97.346 & 1.083 & .340 & \\
\hline & Gruplar içi & 30829.553 & 343 & 89.882 & & & \\
\hline & Toplam & 31024.246 & 345 & & & & \\
\hline \multirow{3}{*}{ Yapılandırılmış } & Gruplar aras1 & 725.152 & 2 & 362.576 & 3,298 & $.038^{*}$ & C-A, \\
\hline & Gruplar içi & 37706.732 & 343 & 109.932 & & & $\mathrm{C}-\mathrm{B}, \mathrm{A}-\mathrm{B}$ \\
\hline & Toplam & 38431.884 & 345 & & & & \\
\hline \multirow{3}{*}{ Toplam } & Gruplar aras1 & 2826.270 & 2 & 1413.135 & 2.774 & .064 & \\
\hline & Gruplar içi & 174760.403 & 343 & 509.506 & & & \\
\hline & Toplam & 177586.673 & 345 & & & & \\
\hline
\end{tabular}

İlişkisiz örneklemler tek yönlü ANOVA testi sonuçlarına göre katılımcıların problem kurma toplam puanlarının sınıf seviyelerine göre anlamlı bir farklılık göstermediği görülmektedir, $\mathrm{F}(2,344)=2.77, \mathrm{p}>.05$. Farklı sınıf seviyelerinde bulunan katılımcıların ortalama puanlarında farklılık olduğu görülmüştür (6. sınıflar için $\bar{X}=85.41$, 7. sınıflar için $\bar{X}=$ 80.20, 8. sınıflar için $\overline{\mathrm{X}}=86.91)$. Fakat bu farkın anlamlı olmadığı belirlenmiştir. Ayrıca katılımcıların farklı problem kurma durumlarından aldıkları puanların sınıf seviyelerine göre anlamlı bir şekilde farklılaşıp farklılaşmadığına bakılmıştır. ANOVA testi sonuçlarına göre 
yapılandırılmış problem kurma durumlarından alınan puanlar öğrencilerin sınıf seviyelerine göre anlamlı bir şekilde farklılaşmaktadır $[\mathrm{F}(2,344)=3.29, \mathrm{p}<.05]$. Bu durum serbest $[\mathrm{F}(2,344)=2.26, \mathrm{p}>.05]$ ve yarı-yapılandırılmış problem kurma durumlarından alınan puanlar $[\mathrm{F}(2,344)=1.08, \mathrm{p}>.05]$ için geçerli değildir. Yapılandırılmış problem kurma durumlarından alınan puanlardaki birimler arası farkların hangi gruplar arasında olduğunun belirlenmesi için Tukey testi yapılmıştır. Tukey testi sonuçlarına göre 8. sınıf (C grubu) ve 6. sınıf (A grubu) katılımcılarının 7. sınıf (B grubu) katılımcılarına göre yapılandırılmış problem kurma becerilerinin daha yüksek olduğu görülmüştür.

Ayrıca ortaokul öğrencilerinin yapılandırılmış problem kurma puanlarındaki varyansın yaklaşık \%2'sinin katılımcıların sınıf seviyelerinden kaynaklandığı belirlenmiştir. Her ne kadar katılımcıların yapılandırılmış problem kurma puanları ile sınıf seviyeleri arasında bir ilişki bulunmuş olsa da bu ilişki düşüktür. Elde edilen bulgulara göre ortaokul öğrencilerinin sınıf seviyeleri ile problem kurma başarı toplam puanları arasında anlamlı bir ilişki olmadığı söylenebilir.

Tablo 7. Matematik başarı seviyelerine göre problem kurma puanlarının betimsel istatistikleri

\begin{tabular}{cccc}
\hline Başarı Seviyesi & $\mathbf{n}$ & $\overline{\mathbf{X}}$ & SS \\
\hline Zayıf(A) & 24 & 60.16 & 6.09 \\
Geçer (B) & 60 & 60.63 & 17.71 \\
Orta (C) & 86 & 81.62 & 16.43 \\
İyi (D) & 82 & 90.82 & 13.28 \\
Çok iyi (E) & 94 & 102.26 & 14.38 \\
Toplam & 346 & 84.28 & 22.68 \\
\hline
\end{tabular}

Katılımcıların matematik akademik başarı seviyelerine göre problem kurma testi puanlarına bakıldığında matematik akademik başarısı arttıkça problem kurma testi ortalama puanlarının da arttığı görülmektedir. Bu doğrultuda matematik dersi başarısı yüksek olan öğrencilerin problem kurma testinden en iyi puanları aldıkları söylenebilir.

Tablo 8. Problem kurma puanlarının matematik başarı seviyelerine göre ANOVA sonuçları

\begin{tabular}{ccccccc}
\hline $\begin{array}{c}\text { Varyansın } \\
\text { Kaynağı }\end{array}$ & Kar. top. & Sd & Kar. ort. & F & p & Anlamlı Fark \\
\hline Gruplar aras1 & 82035.35 & 4 & 20508.83 & 73.191 & .000 & C-A, D-A, E-A, C-B, \\
Gruplar içi & 95551.32 & 341 & 280.20 & & & D-B, E-B, D-C, E-C, \\
Toplam & 177586.67 & 345 & & & & E-D \\
\hline
\end{tabular}

İlişkisiz örneklemler için tek yönlü ANOVA testi sonuçlarına göre katılımcıların problem kurma toplam puanları matematik akademik başarı seviyelerine göre anlamlı bir şekilde farklılaşmaktadır, $\mathrm{F}(4,342)=73.191, \mathrm{p}<.05$. Yapılan hesaplamalara göre problem 
kurma testi toplam puanlarındaki varyansın yaklaşık \%46'sı katılımcıların matematik akademik başarı seviyelerinden kaynaklanmaktadır.

\section{Üçüncü Alt Probleme Yönelik Bulgular}

Tablo 11. Problem kurma öz yeterlik puanlarına ilişkin betimsel istatistiksel bilgiler

\begin{tabular}{ccccc}
\hline $\mathbf{n}$ & Min. & Max. & $\overline{\mathbf{X}}$ & SS \\
\hline 346 & 55.00 & 120.00 & 95.774 & 13.678 \\
\hline
\end{tabular}

Tablo 11 incelendiğinde katılımcıların problem kurmaya yönelik öz yeterlik inançlarının yüksek olduğu görülmektedir. Katılımcıların problem kurmaya yönelik öz yeterlik ölçeğinde 120 tam puan üzerinden ortalama 95.77 puan elde ettikleri görülmektedir. $\mathrm{Bu}$ doğrultuda katılımcıların problem kurmaya yönelik öz yeterliklerinin yüksek olduğu söylenebilir.

\section{Dördüncü Alt Probleme Yönelik Bulgular}

Farklı cinsiyetteki katılımcıların problem kurma öz yeterlik ölçeğinden aldıkları puanlar hakkında fikir edinebilmek amacıyla betimsel istatistikler oluşturulmuştur.

Tablo 12. Cinsiyete göre problem kurma öz yeterlik puanları ile ilgili betimsel istatistikler

\begin{tabular}{ccccccc}
\hline Cinsiyet & n & Min. & Max. & $\overline{\mathbf{X}}$ & SS & ÇK \\
\hline Erkek & 153 & 55.00 & 120.00 & 96.810 & 13.941 & -.482 \\
Kiz & 193 & 56.00 & 120.00 & 94.953 & 13.445 & -.224 \\
Toplam & 346 & 55.00 & 120.00 & 95.774 & 13.678 & -.334 \\
\hline
\end{tabular}

Betimsel istatistikler incelendiğinde kız ve erkek öğrencilerin problem kurma öz yeterlik ölçeğinden aldıkları ortalama puanlar birbirine yakındır. Yine kız ve erkeklerin problem kurma öz yeterlik ölçeğinden aldıkları maksimum ve minimum puanlar da oldukça benzerdir.

Tablo 13. Problem kurma öz yeterlik puanlarının cinsiyete göre t-testi sonuçları

\begin{tabular}{ccccccc}
\hline Cinsiyet & n & $\overline{\mathbf{X}}$ & SS & sd & t & p \\
\hline Erkek & 153 & 96.81 & 13.94 & 344 & 1.255 & .210 \\
Kiz & 193 & 94.95 & 13.44 & & & \\
\hline
\end{tabular}

İlişkisiz örneklemler $\mathrm{t}$ testi sonuçlarına göre problem kurma öz yeterlik ölçeğinden alınan toplam puanlar katılımcıların cinsiyetlerine göre anlamlı farklılık göstermemektedir, $\mathrm{t}(344)=1.255, \mathrm{p}>.05$. Her ne kadar erkeklerin problem kurma öz yeterlik ölçeğinden daha yüksek ortalama puana sahip oldukları görülse de bu fark katılımcıların cinsiyetlerinden kaynaklanmamaktadır. Bu doğrultuda katılımcıların problem kurma öz yeterlik ölçeğinden aldıkları puanların üzerinde cinsiyetlerinin etkisinin olmadığ söylenebilir.

Problem kurma öz yeterlik ölçeğinden alınan puanlar üzerinde olası etkisinin incelendiğinde bir diğer bağımsız değişken katılımcıların sınıf seviyeleridir. Bu doğrultuda 
çalışma grubundaki öğrencilerin sınıf seviyelerine göre problem kurma öz yeterlik ölçeğinden aldıkları puanları ile ilgili istatistiklere bakılmıştır. İlgili betimsel istatistikler Tablo 14 'te sunulmuştur.

Tablo 14. Sınıf seviyesine göre problem kurma öz yeterlik puanları ile ilgili betimsel istatistiksel bilgiler

\begin{tabular}{ccccccc}
\hline Sinıf & $\mathbf{n}$ & Min. & Max. & $\overline{\mathbf{X}}$ & SS & ÇK \\
\hline 6. sinif (A) & 114 & 69.00 & 120.00 & 98.15 & 12.85 & -.349 \\
7. sinif (B) & 110 & 60.00 & 120.00 & 95.69 & 13.18 & -.043 \\
8. sinif (C) & 122 & 55.00 & 120.00 & 93.62 & 14.57 & -.443 \\
Toplam & 346 & 55.00 & 120.00 & 95.77 & 13.67 & -.334 \\
\hline
\end{tabular}

Tablo 14 incelendiğinde katılımcıların problem kurma öz yeterlik inançlarının yüksek olduğu görülmektedir. Problem kurma öz yeterlik inançlarının üst sınıflara gidildikçe düşüş eğiliminde olduğu görülmektedir.

Tablo 15. Problem kurma öz yeterlik puanlarının sınıf seviyelerine göre ANOVA sonuçları

\begin{tabular}{ccccccc}
\hline $\begin{array}{c}\text { Varyansın } \\
\text { Kaynă̆ı }\end{array}$ & Kar. top. & Sd & Kar. ort. & F & p & $\begin{array}{c}\text { Anlaml } \\
\text { Fark }\end{array}$ \\
\hline Gruplar arası & 1213.112 & 2 & 606.556 & 3.285 & .039 & A-C \\
Gruplar içi & 63337.305 & 343 & 184.657 & & & \\
Toplam & 64550.416 & 345 & & & & \\
\hline
\end{tabular}

ANOVA sonuçlarına göre katılımcıların sınıf seviyeleri, problem kurma öz yeterlik ölçeği puanları üzerinde anlamlı bir fark yaratmaktadır, $F(2,343)=3.285, \mathrm{p}<.05$. Bu farkın hangi gruplar arasında olduğunun belirlenmesi amacıyla yapılan Tukey testi sonuçlarına göre anlamlı fark 6. sinıf ve 8. sinıflar arasında ve 6. sinıflar lehinedir. Katılımciların problem kurma öz yeterlik inanç puanlarındaki varyansın yaklaşık \%2'sinin sınıf seviyelerinden kaynaklandığı belirlenmiştir. Bu doğrultuda katılımcıların sınıf seviyelerinin öz yeterlik inançları üzerinde düşük güçte de olsa etkili olduğu görülmektedir.

Tablo 16. Matematik dersi akademik başarı seviyelerine göre problem kurma öz yeterlik puanları ile ilgili betimsel istatistiksel bilgiler

\begin{tabular}{ccccccc}
\hline Başarı & n & Min. & Max. & $\overline{\mathbf{X}}$ & SS & ÇK \\
\hline Zayıf (A) & 19 & 73.00 & 112.00 & 86.94 & 10.56 & 1.181 \\
Geçer (B) & 61 & 60.00 & 120.00 & 90.45 & 12.50 & -.309 \\
Orta (C) & 88 & 55.00 & 120.00 & 91.85 & 13.06 & -.258 \\
İyi (D) & 83 & 55.00 & 120.00 & 97.63 & 13.70 & -.447 \\
Çok iyi (E) & 95 & 56.00 & 120.00 & 102.95 & 11.83 & -.917 \\
Toplam & 346 & 55.00 & 120.00 & 95.77 & 13.67 & -.334 \\
\hline
\end{tabular}


Tablo 16 incelendiğinde katılımcıların matematik akademik başarı seviyeleri arttıkça problem kurma öz yeterlik inanç puan ortalamalarının da sürekli bir artış gösterdiği görülmektedir.

Tablo 17. Problem kurma öz yeterlik puanlarının matematik akademik başarı seviyesine göre ANOVA sonuçları

\begin{tabular}{ccccccc}
\hline $\begin{array}{c}\text { Varyansın } \\
\text { Kaynağı }\end{array}$ & Kar. top. & Sd & Kar. ort. & F & p & Anlamlı Fark \\
\hline Gruplar arası & 9748.254 & 4 & 2437.06 & 15.164 & .000 & E-A, D-A, E-B, D-B, \\
Gruplar içi & 54802.163 & 341 & 160.71 & & & E-C, D-C, E-D \\
Toplam & 64550.416 & 345 & & & & \\
\hline
\end{tabular}

ANOVA sonuçlarına göre katılımcıların problem kurma öz yeterlik ölçeğinden aldıkları puanlar, matematik akademik başarı seviyelerine göre farklılaşmaktadır, $\mathrm{F}(4,341)=$ 15.164, $\mathrm{p}<.05$. Bu anlamlı farklılığın hangi gruplar arasında olduğunun belirlenmesi amacıyla yapılan Tukey testine göre E grubu ile A, B, C, D grupları arasında E grubu lehine anlamlı farklılık belirlenmiştir. Ayrıca D grubu ile A, B, C grupları arasında D grubu lehine anlamlı farklılık görülmüştür. Problem kurma öz yeterlik inancı puanlarındaki varyansın yaklaşık \%15'i katılımcıların matematik dersi akademik başarı seviyelerinden kaynaklanmaktadır. $\mathrm{Bu}$ bağlamda katılımcıların matematik akademik başarı seviyelerinin, problem kurma öz yeterlik ölçeği puanları üzerinde etkili olduğu görülmektedir.

\section{Beşinci Alt Probleme Yönelik Bulgular}

Ortaokul öğrencilerinin problem kurmaya yönelik öz yeterlik inançlarının, problem kurma becerilerinin anlamlı bir yordayıcısı olup olmadığının belirlenmesi amacıyla basit doğrusal regresyon analizi uygulanmıştır.

Tablo 18. Problem kurmaya yönelik beceri ve öz yeterlik inanç değişkenlerine ait basit doğrusal regresyon analizi sonuçları

\begin{tabular}{lllllll}
\hline Değişken & B & SH$_{\mathbf{B}}$ & $\boldsymbol{\beta}$ & $\mathbf{t}$ & $\mathbf{p}$ & $\mathbf{R}$ \\
\hline Sabit & 41,926 & 8,338 & - & 5,028 &, 000 & \\
Öz yeterlik &, 442 &, 086 &, 267 & 5,132 &, 000 & .267 \\
\hline $\mathrm{R}=0.26, \mathrm{R}^{2}=0.071, \mathrm{~F}(1,344)$ & $=26.333, \mathrm{p}<.05$ & & & & \\
\hline
\end{tabular}

Regresyon analizi sonuçlarına göre katılımcıların problem kurmaya yönelik öz yeterlik inançları, problem kurma becerilerini anlamlı bir şekilde yordamaktadır, $\left(\mathrm{R}=0.267, \mathrm{R}^{2}=0.071\right)$. Katılımcıların problem kurmaya yönelik becerileri ve öz yeterlikleri arasında düşük düzeyde pozitif bir anlamlı ilişki bulunmaktadır, $r=0.267$. Veriler, problem kurma becerisi puanlarındaki varyansın yaklaşık \% 7'sinin katılımcıların problem kurmaya yönelik öz yeterlik inançlarından kaynaklandığını göstermektedir. Bu doğrultuda katılımcıların problem kurma 
testlerindeki başarılarının, problem kurmaya yönelik öz yeterlik inançları ile ilişkili olduğu söylenebilir.

\section{Tartışma, Sonuç ve Öneriler}

Verilerin analizi sonucunda araştırmaya katılan altıncı, yedinci ve sekizinci sınıf öğrencilerinin örüntü problemi kurma becerilerinin genel olarak iyi seviyede olduğu görülmüştür. İlgili literatürde benzer sonuçların elde edildiği çalışmalar mevcuttur (Cai, 1998; Cai, 2003; Silver \& diğ., 1996). Cai (2003) dördüncü, beşinci ve altıncı sınıf öğrencileri ile yaptığı çalışmada katılımcıların çoğunun örüntü problemi kurmada başarılı olduğunu belirtmiştir. Aynı şekilde öğrenciler, öğretmen adayları ve öğretmenler ile yapılan birçok çalışmada katılımcıların problem kurma etkinliklerinde başarılı oldukları görülmüştür (Cai, 1998; Cai, Chen, Li, Xu, Zhang, Yu, Zhang \& Song, 2019; Ev-Çimen \& Y1ldı, 2018; Silver \& diğ., 1996; Silver \& Cai, 1996 Şengül-Akdemir \& Türnüklü, 2017; Ünlü \& Sarpkaya-Aktaş, 2017). Araştırmanın sonuçları ile benzerlik gösteren çalışmaların yanı sıra çelişen sonuçların elde edildiği çalışmalara da rastlanmaktadır (Arıkan \& Ünal, 2015; Çelik \& Yetkin-Özdemir, 2011; Geçici, 2018; Kılıç, 2019; Özgen \& diğ., 2017; Türnüklü, Ergin \& Aydoğdu, 2017; Y1lmaz, Durmuş \& Yaman, 2018). Kılıç (2019) ortaokul öğrencilerinin örüntü arama stratejisi ile çözülebilecek problemler kurma becerilerinin düşük olduğunu ortaya koymuştur. Benzer şekilde Özgen ve diğg. (2017) ortaokul öğrencilerinin problem kurmada zorlandıkları ve problem kurma becerilerinin bir hayli düşük olduğunu belirtmişlerdir. İlgili çalışmalara bakıldığında ortaokul öğrencilerinin problem kurma etkinliklerinde başarılı oldukları çalışmalar kadar başarısız oldukları çalışmaların da mevcut olduğu görülmektedir.

Ortaokul öğrencilerinin problem kurma becerilerinin; problem kurma konusundaki deneyimleri, akademik başarı durumları, içerik bilgileri, etkinliklerin içeriği vb. birçok değişken tarafından etkilendiği düşünülmektedir. Öğrenciler bir matematik konusuna yönelik problem kurabilirken, farklı bir matematik konusuna yönelik problem kuramayabilir. Problem kurma etkinliklerinin açık uçlu olmaları sebebiyle (Kovacs, 2017) farklı durumlarda farklı sonuçlar elde edilmesinin mümkün olacağı yorumu yapılabilir. Problem kurma ile ilgili yapılan farklı çalışmalarda benzer ya da farklı sonuçların elde edilmesi, aynı zamanda mevcut çalışmadaki katılımcıların farklı problem kurma durumlarında farklı başarı göstermeleri bu duruma bağlanabilir.

Farklı sınıf seviyelerindeki katılımcılar ile yapılan problem kurma çalışmaları incelendiğinde ortak bir görüş olmadığı görülmektedir (Cai, 2003; Ekici, 2016). Cai (2003) çalışmasında sınıf seviyeleri arttıkça katılımcıların etkinliklerde daha başarılı olduklarını ve 
daha soyut stratejiler kullanabildiklerini belirtmiştir. Cai'nin (2003) çalışması bu yönüyle bu araştırmanın sonuçları ile kısmi benzerlikler göstermektedir. Ekici (2016) ise çalışmasında problem kurma becerileri açısından farklı sınıf seviyelerindeki katılımcılar arasında belirgin bir ayrıma rastlamamıştır. Bu bilgiler ışı̆̆ında ortaokul öğrencilerinin sınıf seviyeleri arttıkça daha soyut düşünebilecekleri ve daha derin içerik bilgilerine sahip olacakları düşünüldüğünde problem kurma becerilerinin artması beklenebilir. Fakat farklı sınıf seviyelerindeki katılımcıların akademik ve sosyal özelliklerinin farklı olabileceğinden dolayı bu görüş her zaman doğrulanmayabilir. Nitekim bu çalışmada üst sınıf seviyelerindeki katılımcıların alt sınıf seviyesindeki katılımcılara göre problem kurma etkinliklerinde daha başarısız olduğu durumlar görülmüştür. Bu konu ile ilgili daha sağlıklı bilgilerin ileride yapılacak boylamsal araştırmalar ile elde edilebileceği düşünülmektedir.

Katılımcıların farklı problem kurma durumlarındaki problem kurma becerileri de incelenmiştir. Araştırmada elde edilen sonuçlara göre katılımcılar en yüksek puanları serbest problem kurma durumlarında elde ederken, en düşük puanları yapılandırılmış problem kurma durumlarında elde etmişlerdir. Farklı problem kurma durumları ile ilgili etkinlikler içeren çalışmalar incelendiğinde farklı sonuçlar göze çarpmaktadır. Ngah ve diğerleri (2016) ortaokul öğrencilerinin serbest problem kurma durumlarında diğer problem kurma durumlarına göre daha fazla zorlandıklarını belirtmişlerdir. Kılıç (2013) ise sınıf öğretmeni adaylarının farklı problem kurma durumlarında karşılaştıkları güçlükleri araştırdığ çalışmada serbest problem kurma durumlarında, yarı-yapılandırılmış ve yapılandırılmış problem kurma durumlarına göre daha az sayıda katılımcının güçlük yaşadığını ortaya koymuştur. İlgili çalışmalar incelendiğinde bu araştırmanın sonuçlarına benzer sonuçlar elde edilen çalışmaların yanı sıra, farklı sonuçlar elde edilen çalışmaların da olduğu görülmektedir (Geçici \& Aydın, 2019; Özgen $\&$ diğ, 2019). Serbest problem kurma durumlarında daha az sınırlamaların olması öğrencilerin bu problem kurma durumlarında daha kolay problem kurabilmelerini sağlamış olabilir. Yapılandırılmış problem kurma durumlarında ise sınırlamalar olabildiğince fazladır. Ayrıca bu araştırmanın katılımcılarının yarı-yapılandırılmış ve yapılandırılmış problem kurma durumlarında zorlanmaları problem kurma stratejileri konusunda yeterli bilgiye sahip olmamalarından kaynaklanmış olabilir. Zira katılımcıların yapılandırılmış problem kurma durumlarında mevcut problemdeki sayıları ya da konuyu değiştirerek basit bir şekilde problem kurabilmeleri mümkün olmaktadır. Ayrıca farklı problem kurma durumlarının zorluk seviyelerinin etkinlikten etkinliğe değişebileceği de düşünülmektedir. 
Araştırmada katılımcıların problem kurma becerileri ile bazı bağımsız değişkenler arasındaki ilişkiler de incelenmiştir. Bu doğrultuda katılımcıların problem kurma becerileri ile cinsiyetleri arasında anlamlı bir ilişki olup olmadığına bakılmış ve anlamlı bir ilişki bulunamamıştır. Cinsiyetin matematiksel becerileri üzerindeki etkisi ile ilgili farklı sonuçlar elde eden çalışmalar mevcuttur (Geçici \& Aydın, 2019; Korkut, 2002). Yapılan çalışmalar farklı toplumlarda cinsiyetin akademik beceriler üzerindeki etkisinin değişkenlik gösterdiğini göstermektedir (Reilly, Neumann \& Andrews, 2019). Bu doğrultuda farklı örneklemlerde cinsiyetin problem kurma becerileri üzerindeki etkisinin farklı olmasının normal olduğu düşünülmektedir.

Katılımcıların problem kurma becerileri ile ilişkisi araştırılan bir diğer bağımsız değişken katılımcıların akademik başarılarıdır. Bulgular yüksek matematik başarısına sahip katılımcıların problem kurma testlerinde daha başarılı olduğunu göstermektedir. Ellerton (1986) matematikte başarılı ve daha az başarılı olan iki grup öğrenci ile yaptığı çalışmasında başarılı gruptaki öğrencilerin problem kurma konusunda çok daha üstün olduklarını göstermiştir. Yuan ve Sriraman (2011) lise öğrencilerinin problem kurma becerilerinin diğer matematiksel beceriler ve içerik bilgileri ile doğrudan ilişkili olduğunu belirtmişlerdir. Benzer şekilde bu araştırmanın sonucu ile benzerlik gösteren birçok çalışma mevcuttur (Çelik \& Yetkin-Özdemir, 2011; Dikkartın-Övez \& Çınar, 2018; Ekici, 2016; Geçici \& Aydın, 2019; Özgen \& diğ., 2017; Silver ve Cai, 1996). Öğrencilerin matematik başarılarının matematiksel becerilerdeki yetkinliklerine bağlı olduğu düşünüldüğünde araştırmanın bu sonucu daha anlamlı olmaktadır. İlgili araştırmalar incelendiğinde bu araştırmanın sonuçları ile farklılık gösteren sonuçlara sahip çalışmaların da olduğu görülmüştür. Arıkan ve Ünal (2015) akademik başarı açısından farklı iki sınıf ile yaptıkları çalışmada iki grup arasında problem kurma becerileri açısından belirgin bir fark gözlenmediğine işaret etmişlerdir. Tüm bu bulgular doğrultusunda ortaokul öğrencilerinin matematik akademik başarılarının problem kurma becerileri üzerinde etkili olduğu sonucuna varılabilir. Günümüz matematik öğretim programlarında problem çözme ve problem kurma önemli birer matematiksel beceri olarak ele alınmaktadır (MEB, 2018). Bu doğrultuda öğrencilerin matematikte başarılı olabilmeleri için bu becerilere sahip olmaları ve bunları geliştirebilmeleri gerekir. Sonuç olarak matematik akademik başarısı yüksek öğrencilerin bu becerilere sahip oldukları yorumu yapılabilir.

Araştırmada ortaokul öğrencilerinin problem kurma becerilerinin yanı sıra problem kurmaya yönelik öz yeterlik inançları da belirlenmeye çalışılmıştır. Bu doğrultuda elde edilen veriler katılımcıların problem kurmaya yönelik öz yeterlik inançlarının yüksek olduğunu 
göstermektedir. Bu konuda yapılan çalışmalar incelendiğinde benzer sonuçların elde edildiği çalışmalara rastlanmıştır (Nicolau \& Philippou, 2007; Pajares, 1996). Nicolaou ve Philippou (2007) çalışmalarında ortaokul öğrencilerinin problem kurmaya yönelik öz yeterliklerinin bir hayli yüksek olduğunu belirtmişlerdir. Problem kurma öz yeterlik inançlarının yanı sıra matematik öz yeterlik inançlarını araştıran çalışmalar da mevcuttur (Doruk, Öztürk \& Kaplan, 2016; Pajares, 1996). Doruk, Öztürk ve Kaplan (2016) çalışmalarında ortaokul öğrencilerinin matematik öz yeterlik algılarının ve matematiğe yönelik tutumlarının yüksek olduğu belirtmişlerdir. Benzer şekilde Pajares (1996) çalışmasında öğrencilerin yüksek matematik öz yeterlik algılarına sahip olduklarını belirtmiştir. Bu araştırmada da belirlendiği üzere ortaokul öğrencileri ve öğretmen adayları ile yapılan çalışmalarda katılımcıların matematiğe veya matematiksel becerilere yönelik öz yeterlik inançlarının genel olarak yüksek olduğu anlaşılmaktadır (Çağırgan-Gülten, 2013; Doruk, Öztürk \& Kaplan, 2016, Nicolaou \& Philippou, 2007; Pajares, 1996). Bu araştırmanın katılımcıları genel olarak akademik başarıları iyi düzeyde olan öğrencilerden oluşmaktadır. Akademik başarı ile öz yeterlik inançları arasında pozitif bir ilişki olduğu göz önüne alındığında (Hackett \& Betz, 1989) katılımcıların yüksek öz yeterlik inançlarına sahip olmalarının beklenebilir bir durum olduğu düşünülmektedir.

Katılımcıların problem kurmaya yönelik öz yeterlik inançları ile bazı bağımsız değişkenler arasındaki ilişkiler incelenmiştir. Erkek öğrencilerin problem kurmaya yönelik öz yeterlik ölçeğinden aldıkları ortalama puanlar kız öğrencilerin ortalama puanlarından yüksek olsa da bu farkın cinsiyetten kaynaklanmadığı söylenebilir. Bu konuda yapılan geçmiş çalışmalara bakıldığında farklı sonuçların elde edildiği görülmektedir. Erkek öğrencilerin öz yeterlik algılarının yüksek olduğunu belirten çalışmaların (Adal \& Yavuz, 2017; Hackett \& Betz, 1989; Matsui, Matsui \& Ohnishi, 1990; Pajares \& Miller, 1994) yanı sıra kızların öz yeterlik algılarının erkeklere göre daha yüksek olduğunu gösteren çalışmalar da mevcuttur (Arslan, 2017; Koç \& Arslan, 2017). Ayrıca cinsiyetin öz yeterlik inançları üzerinde etkisinin olmadığını belirten çalışmalar da mevcuttur (Ayotola \& Adedeji, 2009; Bandura \& Schunk, 1981; Pajares \& Graham, 1999).

Farklı sınıf seviyelerinde yer alan katılımcıların öz yeterlik ölçeğinden aldıkları ortalama puanlara bakıldığında, sınıf seviyesi arttıkça öz yeterlik ölçeği puanlarının düşüş eğiliminde olduğu görülmektedir. Analizler katılımcıların problem kurmaya yönelik öz yeterlik inançları ile sınıf seviyeleri arasında anlamlı bir ilişki olduğunu göstermektedir. Bu anlamlı ilişskinin 6. ve 8. sınıflar arasındaki farktan kaynaklandığı belirlenmiştir. Bu doğrultuda ortaokul öğrencilerinin sınıf seviyelerinin problem kurmaya yönelik öz yeterlik inançları 
üzerinde etkili olduğu söylenebilir. Araştırmanın bu sonucu konu ile ilgili yapılmış bazı çalışmalar ile benzerlikler göstermektedir (Adal \& Yavuz, 2017; Arslan, 2017; Koç \& Arslan, 2017). Koç ve Arslan'ın (2017) çalışmasında 5. sınıf öğrencilerinin akademik öz yeterlik algılarının 6., 7. ve 8. sınıf öğrencilerin akademik öz yeterlik algılarına göre daha yüksek olduğuna ulaşılmıştır. Ayrıca aynı çalışmada katılımcıların sınıf seviyeleri ile akademik öz yeterlik algıları arasında anlamlı bir ilişki olduğu belirtilmiştir (Koç \& Arslan, 2017). Bu araştırmanın sonuçlarıyla çelişen araştırmalar da mevcuttur. Öğretmen adayları ile yapılan bazı çalışmalarda ise öz yeterlik algılarının üst sınıflarda, alt sınıflardaki katılımcılara oranla daha yüksek olduğu belirtilmiştir (Furat-Durdukoca, 2010). Araştırmada elde edilen bu sonucun öğrencilerin üst sınıflara geçtikçe motivasyon kaybı yaşamaları, ders kazanımlarının artması ve zorlaşması gibi sebeplerden kaynaklanmış olabileceği düşünülmektedir. Ayrıca çocukların yaşları büyüdükçe ailelerinin eğitime katılımının azaldığı bilinmektedir (Fan \& Chen, 2001). $\mathrm{Bu}$ doğrultuda aileleri tarafindan eskisi gibi motive edilmeyen ve okul hayatlarında yakın destek görmeyen çocukların öz yeterliklerinin yıllar geçtikçe düşmesi beklenebilir.

Katılımcıların problem kurmaya yönelik öz yeterlik inançları üzerindeki etkisi incelenen bir diğer bağımsız değişken, akademik başarı durumlarıdır. Bu doğrultuda yapılan analizler sonucunda katılımcıların matematik akademik başarıları ile problem kurmaya yönelik öz yeterlik ölçeğinden aldıkları puanlar arasında anlamlı ilişki bulunmuştur. $\mathrm{Bu}$ bulgular 1şı̆̆ında katılımcıların akademik başarı seviyelerinin problem kurmaya yönelik öz yeterlik inançları üzerinde etkili olduğu yorumu yapılabilir. Araştırmada elde edilen bu sonuç bu konuda yapılmış birçok çalışma ile benzerlik göstermektedir (Ayotola \& Adedeji, 2009; Pajares \& Graham, 1999; Skaalvik, Federici \& Klassen, 2015; Zimmerman, 2000). Tüm bu bulgular öz yeterlik inançlarının akademik başarı için belirleyici bir etken olduğu görüşünü desteklemektedir (Bandura, 1986). Bandura' ya (1997) göre kişinin başarılı olduğu her deneyim öz yeterlik algılarını yükseltmekte, başarısız olduğu deneyimler ise öz yeterlik algılarını düşürmektedir. $\mathrm{Bu}$ doğrultuda öz yeterlik inançları yüksek olan ortaokul öğrencilerinin akademik olarak başarılı olmaya daha yatkın oldukları ve akademik olarak başarılı oldukça öz yeterliklerinin yükseldiği söylenebilir.

Katılımcıların problem kurma becerileri ile problem kurmaya yönelik öz yeterlikleri arasında ilişki olup olmadığının belirlenmesi için regresyon analizi yapılmıştır. Analiz sonuçlarına göre katılımcıların problem kurma becerileri ile problem kurmaya yönelik öz yeterlik inançları arasında düşük düzeyde pozitif bir ilişski bulunmuştur. $\mathrm{Bu}$ doğrultuda katılımcıların problem kurmaya yönelik öz yeterlik inançlarını problem kurma becerilerinin 
yordayıcısı olduğu söylenebilir. Araştırma öncesinde ortaokul öğrencilerinin problem kurma becerileri ile problem kurmaya yönelik öz yeterlik inançları arasındaki ilişkinin daha güçlü olacağı öngörülmüştür. Katılımcıların problem kurma becerileri ile öz yeterlikleri arasındaki ilişkinin beklenenden daha az güçlü çıkması katılımcıların problem kurma konusunda aşırı öz güvenli olmalarından ve problem kurma konusundaki kapasitelerini isabetli bir şekilde belirleyemediklerinden dolayı olmuş olabilir. $\mathrm{Bu}$ konu ile ilgili yapılan çalışmalarda benzer sonuçlara rastlanmaktadır (Hackett \& Betz, 1989; Pajares, 1996). Hackett ve Betz (1989) üniversite öğrencilerinin matematik başarıları ile matematik öz yeterlikleri arasında ilişki olduğunu fakat öğrencilerin matematik öz yeterlikleri ile ilgili isabetli yargılarda bulunamadıklarını belirtmişlerdir. Benzer şekilde öğrencilerin çoğunun problem çözme yetenekleri konusunda aşırı öz güvenli oldukları ortaya konmuştur (Pajares, 1996). Bu sonuçlardan yola çıkarak ortaokul öğrencilerinin problem kurmaya yönelik öz yeterlik inançları yüksek olsa da problem kurma becerileri hakkındaki algılarının çok isabetli olmadığı yorumu yapılabilir.

Araştırmada öğrencilerin problem kurma becerilerinin akademik başarı seviyeleri ile ilişkili olduğu belirlenmiştir. Öğrencilerin problem kurma etkinlikleri ile daha fazla deneyim yaşamaları sağlanmalı ve bu doğrultuda akademik başarı düzeylerine katkı sağlanmalıdır. Katılımcıların serbest problem kurma durumlarında diğer problem kurma durumlarına göre daha başarılı oldukları görülmüştür. Ortaokul öğrencilerinin belirli problem kurma stratejilerinin bilinmesini gerektirebilen yarı-yapılandırılmış ve yapılandırılmış problem kurma durumlarında daha başarılı olabilmeleri için bu stratejiler konusunda eğitilmelidirler. Ortaokul öğrencilerinin problem kurma becerileri ile problem kurmaya yönelik öz yeterlikleri arasında anlamlı bir ilişki olduğu belirlenmiştir. Tüm öğrencilerin problem kurma konusunda deneyim kazanmaları ve bu konuda öz güven sahibi olmaları, bu etkinlikleri yapabileceklerine inanmalarının sağlanması problem kurma becerilerinin geliştirilmesi açısından önemlidir.

\section{Makalenin Bilimdeki Konumu}

\section{Matematik ve Fen Bilimleri Eğitimi/Matematik Eğitimi}

\section{Makalenin Bilimdeki Özgünlüğü}

Problem kurma ile ilgili araştırmalar incelendiğinde ortaokul öğrencilerinin problem kurma becerileri, problem kurmaya yönelik öz yeterlikleri ve bu ikisi arasındaki ilişkinin incelendiği çalışmalar sınırlıdır. 


\section{Kaynaklar}

Adal, A.A., \& Yavuz, İ. (2017). Ortaokul öğrencilerinin matematik öz yeterlik algıları ile matematik kaygı düzeyleri arasındaki ilişki. Uluslararası Alan Eğitimi Dergisi, 3(1), 2041.

Akay, H., Soybaş, D., \& Argün, Z. (2006). Problem kurma deneyimleri ve matematik öğretiminde açık-uçlu soruların kullanımı. Kastamonu Eğitim Dergisi, 14(1), 129146.

Akkan, Y., Çakıroğlu, Ü., \& Güven, B. (2009). İlköğretim 6. ve 7. sınıf öğrencilerinin denklem oluşturma ve problem kurma yeterlilikleri. Mehmet Akif Ersoy Üniversitesi Eğitim Fakültesi Dergisi, 9(17), 41-55.

Arıkan, E. E. \& Ünal, H. (2015). An investigation of eighth grade students' problem posing skills (Turkey sample). International Journal of Research in Education and Science, $1(1), 23-30$.

Arslan, A. (2017). Investigation of secondary school students' listening anxiety and academic self-efficacy beliefs in terms of various variables. International e-Journal of Educational Studies, 1(1), 12-31.

Ayotola, A., \& Adedeji, T. (2009). The relationship between mathematics self-efficacy and achievement in mathematics. Procedia-Social and Behavioral Sciences, 1(1), 953957.

Bandura, A. (1977). Social learning theory. Englewood Cliffs, NJ, US: Prentice-Hall, Inc.

Bandura, A. (1986). Social foundations of thought and action: A social cognitive theory. Englewood Cliffs, NJ, US: Prentice-Hall, Inc.

Bandura, A. (1997). Self-efficacy: The exercise of control. New York: W.H. Freeman and Company.

Bandura, A., \& Schunk, D. H. (1981). Cultivating competence, self-efficacy, and intrinsic interest through proximal self-motivation. Journal of Personality and Social Psychology, 41 (3), 586-598.

Brown, S. I., \& Walter, M. I. (2005). The art of problem posing (3rd ed.). New York: Psychology Press.

Cai, J. (1998). An investigation of US and Chinese students' mathematical problem posing and problem solving. Mathematics Education Research Journal, 10(1), 37-50. 
Cai, J. (2003). Singaporean students' mathematical thinking in problem solving and problem posing: An exploratory study. International Journal of Mathematical Education in Science and Technology, 34(5), 719-737.

Cai, J., \& Hwang, S. (2002). Generalized and generative thinking in US and Chinese students' mathematical problem solving and problem posing. Journal of Mathematical Behavior, 21(4), 401-421.

Cai, J., Moyer, J. C., Wang, N., Hwang, S., Nie, B., \& Garber, T. (2013). Mathematical problem posing as a measure of curricular effect on students' learning. Educational Studies in Mathematics, 83(1), 57-69.

Cai, J., Chen, T., Li, X., Xu, R., Zhang, S., Hu, Y., Zhang, L., \& Song, N. (2019). Exploring the impact of a problem-posing workshop on elementary school mathematics teachers' conceptions on problem posing and lesson design. International Journal of Educational Research. https://doi.org/10.1016/j.ijer.2019.02.004.

Christou, C., Mousoulides, N., Pittalis, M., Pitta-Pantazi, D., \& Sriraman, B. (2005). An empirical taxonomy of problem posing processes. ZDM, 37(3), 149-158.

Çağırgan-Gülten, D. (2013). An investigation of pre-service primary mathematics teachers' math literacy self-efficacy beliefs in terms of certain variables. International Online Journal of Educational Sciences, 5(2), 393-408.

Çelik, A., \& Yetkin-Özdemir, E. (2011). İlköğretim öğrencilerinin orantısal akıl yürütme becerileri ile oran-orantı problemi kurma becerileri arasındaki ilişki. Pamukkale Üniversitesi Eğitim Fakültesi Dergisi, 30(1), 1-11.

Dikkartın Övez, F.T., \& Çınar, B.A. (2018). Ortaokul 8. sınıf öğrencilerinin cebir bilgileri ve cebirsel düşünme düzeylerinin problem kurma becerileri açısından incelenmesi. Balıkesir Üniversitesi Fen Bilimleri Enstitüsü Dergisi, 20(1), 483-502.

Doruk, M., Öztürk, M., \& Kaplan, A. (2016). Ortaokul öğrencilerinin matematiğe yönelik özyeterlik algılarının belirlenmesi: Kaygı ve tutum faktörleri. Adıyaman Üniversitesi Eğitim Bilimleri Dergisi, 6(2), 283-302.

Ekici, D. (2016). Ortaokul ögrrencilerinin problem kurma stratejilerinin belirlenmesi. (Yayımlanmamış yüksek lisans tezi). Dokuz Eylül Üniversitesi, İzmir.

Ellerton, N.F. (1986). Children's made-up mathematics problems - a new perspective on talented mathematicians. Educational Studies in Mathematics, 17(3), 261-271.

English, L.D. (1997). The development of fifth-grade children's problem-posing abilities. Educational Studies in Mathematics, 34(3), 183-217. 
English, L.D. (1998). Children's problem posing within formal and informal contexts. Journal for Research in Mathematics Education, 29(1), 83-106.

English, L., \& Sriraman, B. (2010). Problem solving for the 21 st century. In Sriraman B., English L. (Eds.) Theories of mathematics education (pp. 263-290). Berlin: Springer.

Ev-Çimen, E., \& Yıldız, Ş. (2018). Altıncı sınıf öğrencilerinin sütun grafiğine uygun problem kurma becerilerinin incelenmesi. Mehmet Akif Ersoy Üniversitesi Eğitim Fakültesi Dergisi, 48, 325-354.

Fan, X., \& Chen, M. (2001). Parental involvement and students' academic achievement: A meta-analysis. Educational Psychology Review, 13(1), 1-22.

Fırat-Durdukoca, Ş. (2010). Sınıf öğretmeni adaylarının akademik öz yeterlik algılarının çeşitli değişkenler açısından incelenmesi. Abant İzzet Baysal Üniversitesi Dergisi, 10(1), 69-77.

Geçici, M.E. (2018). Sekizinci sınıf ögrencilerinin geometri problemi kurma becerilerinin incelenmesi. (Yayımlanmamış yüksek lisans tezi). Dicle Üniversitesi, Diyarbakır.

Geçici, M.E., \& Aydın, M. (2019). Sekizinci sınıf öğrencilerinin geometri problemi kurma becerileri ile geometri öz-yeterlik inançları arasındaki ilişkinin incelenmesi. Kuramsal Eğitimbilim Dergisi, 12(2), 431-456.

Gonzales, N. A. (1998). A blueprint for problem posing. School Science and Mathematics, 98(8), 448-456.

Grootenboer, P., \& Marshman, M. (Ed.) (2016). The affective domain, mathematics, and mathematics education. In Mathematics, affect and learning (pp. 13-33). Springer, Singapore.

Hackett, G., \& Betz, N.E. (1989). An exploration of the mathematics selfefficacy/mathematics performance correspondence. Journal for Research in Mathematics Education, 20(3), 261-273.

Hekimoglu, S., \& Kittrell, E. (2010). Challenging students' beliefs about mathematics: The use of documentary to alter perceptions of efficacy. Problems, Resources, and Issues in Mathematics Undergraduate Studies, 20(4), 299-331.

Hoffman, B. (2010). "I think I can, but I'm afraid to try": The role of self-efficacy beliefs and mathematics anxiety in mathematics problem-solving efficiency. Learning and Individual Differences, 20(3), 276-283. 
Katranc1, Y., \& Şengül, S. (2019). Ortaokul öğrencilerinin matematik problemi oluşturma, matematik problemi çözme ve matematiğe yönelik tutumları arasındaki ilişkiler. Eğitim ve Bilim, 44(197), 1-24.

Kılıç, Ç. (2013). Sınıf öğretmeni adaylarının farklı problem kurma durumlarında sergilemiş oldukları performansın belirlenmesi. Kuram ve Uygulamada Eğitim Bilimleri, 13(2), 1195-1211.

Kılıç, Ç. (2019). Örüntü arama stratejisi ile çözülebilecek problemleri kurmada ortaokul öğrencilerinin performanslarının incelenmesi. Kastamonu Ĕ̆itim Dergisi, 27(2), 647656.

Kilpatrick, J. (1987). Problem formulating: Where do good problems come from? In A. H. Schoenfeld (Ed.), Cognitive science and mathematics education (pp. 123-147). New Jersey, Lawrence Erlbaum Associates, Inc.

Koç, C., \& Arslan, A. (2017). Ortaokul öğrencilerinin akademik öz yeterlik algıları ve okuma stratejileri bilişüstü farkındalıkları. Yüzüncü Yıl Üniversitesi Eğitim Fakültesi Dergisi, 14(1), 745-778.

Korkut, F. (2002). Lise öğrencilerinin problem çözme becerileri. Hacettepe Üniversitesi Ĕ̈itim Fakültesi Dergisi, 23, 177-184.

Kovács, Z. (2017). Mathematic teacher trainees facing the "what-if-not" strategy: A case study. In A. Ambrus, \& É. Vásárhelyi (Eds.), Problem solving in mathematics education (pp. 68-81), Hungary, Budapest: Eötvös Loránd University.

Leung, S.S. (2013). Teachers implementing mathematical problem posing in the classroom: Challenges and strategies. Educational Studies in Mathematics, 83(1), 103-116.

Matsui, T., Matsui, K., \& Ohnishi, R. (1990). Mechanisms underlying math self-efficacy learning of college students. Journal of Vocational Behavior, 37(2), 225-238.

Miles, M.B., \& Huberman, A.M. (1994). An expanded source book: Qualitative data analysis. London: Sage Publications.

Milli Eğitim Bakanlığı [MEB]. (2013). Ortaokul matematik dersi (5, 6, 7 ve 8. Sinfflar) öğretim programı. Ankara: MEB Basımevi.

Milli Eğitim Bakanlığı [MEB]. (2018). Matematik dersi ögretim programı (İlkokul ve Ortaokul 1, 2, 3, 4, 5, 6, 7 ve 8. Sinıflar). Ankara: MEB Basımevi.

Ngah, N., Ismail, Z., Tasir, Z., \& Mohamad Said, M.N.H. (2016). Students' ability in free, semi-structured and structured problem posing situations. Advanced Science Letters, 22(12), 4205-4208. 
Nicolaou, A.A., \& Philippou, G.N. (2007). Efficacy beliefs, problem posing, and mathematics achievements. In D. Pitta-Pantazi, \& G. Phillippou (Eds.), Proceedings of the $V$ Congress of the European Society for Research in Mathematics Education (pp. 308-317). Larnaca, Department of Education, University of Cyprus.

Nixon-Ponder, S. (1995). Using problem-posing dialogue: In adult literacy education. Adult Learning, 7(2), 10-12.

Özgen, K., \& Bayram, B. (2019). Problem kurma öz yeterlik ölçeğinin geliştirilmesi. Illkögretim Online, 18(2), 663-680.

Özgen, K., Aydın, M., Geçici, M.E., \& Bayram, B. (2017). Sekizinci sınıf öğrencilerinin problem kurma becerilerinin bazı değişkenler açısından incelenmesi. Türk Bilgisayar ve Matematik Eğitimi Dergisi, 8(2), 218-243.

Özgen, K., Aydın, M., Geçici, M. E., \& Bayram, B. (2019). An investigation of eighth grade students' skills in problem-posing. International Journal for Mathematics Teaching \& Learning, 20(1), 106-130.

Pajares, F. (1996). Self-efficacy beliefs in academic settings. Review of Educational Research, 66(4), 543-578.

Pajares, F., \& Graham, L. (1999). Self-efficacy, motivation constructs, and mathematics performance of entering middle school students. Contemporary Educational Psychology, 24(2), 124-139.

Pajares, F., \& Miller, M.D. (1994). Role of self-efficacy and self-concept beliefs in mathematical problem solving: A path analysis. Journal of Educational Psychology, 86(2), 193-203.

Polya, G. (1973). How to solve it: A new aspect of mathematical method. New Jersey: Princeton University Press.

Reilly, D., Neumann, D.L., \& Andrews, G. (2019). Investigating gender differences in mathematics and science: Results from the 2011 trends in mathematics and science survey. Research in Science Education, 49(1), 25-50.

Ruane, J.M. (2005). Essentials of research methods - A guide to social science research. Blackwell Publishing, Australia.

Semizoğlu, R. (2013). İlköğretim 5. Sinıf öğrencilerinin okuduğunu anlama ve görsel okuma düzeyi ile problem kurma becerisi arasındaki ilişkinin incelenmesi. (Yayımlanmamış yüksek lisans tezi). Gazi Üniversitesi, Ankara. 
Silver, E.A. (1987). Foundations of cognitive theory and research for mathematics problemsolving instruction. In Cognitive Science and Mathematics Education (Ed. Schoenfeld H. A.). New Jersey: Routledge.

Silver, E.A., \& Cai, J. (1996). An analysis of arithmetic problem posing by middle school. Journal for Research in Mathematics Education, 27(5), 521-539.

Silver, E.A., Mamona-Downs, J., Leung, S.S., \& Kenney, P.A. (1996). Posing mathematical problems: An exploratory study. Journal for Research in Mathematics Education, 27(3), 293-309.

Skaalvik, E.M., Federici, R.A., \& Klassen, R.M. (2015). Mathematics achievement and selfefficacy: Relations with motivation for mathematics. International Journal of Educational Research, 72(1), 129-136.

Stoyanova, E., \& Ellerton, N.F. (1996). A framework for research into students' problem posing in school mathematics. In P. Clarkson (Ed.), Technology in mathematics education (pp.518-525), Melbourne: Mathematics Education Research Group of Australasia.

Şengül-Akdemir, T., \& Türnüklü, E. (2017). Ortaokul 6. sınıf öğrencilerinin açılar ile ilgili problem kurma süreçlerinin incelenmesi. International Journal of New Trends in Arts, Sports \& Science Education, 6(2), 17-39.

Teddlie, C., \& Yu, F. (2007). Mixed methods sampling: A typology with examples. Journal of Mixed Methods Research, 1(1), 77-100.

Tichá, M., \& Hošpesová, A. (2009). Problem posing and development of pedagogical content knowledge in pre-service teacher training. In V. Durand-Guerrier, S. SouryLavergne, \& F. Arzarello (Eds.), Proceedings of the Sixth Congress of the European Society for Research in Mathematics Education (pp. 1941-1950). Lyon: Institute National de Recherche Pédagogique.

Toluk-Uçar, Z. (2009). Developing pre-service teachers understanding of fractions through problem posing. Teaching and Teacher Education, 25(1), 166-175.

Türnüklü, E., Ergin, A.S. \& Aydoğdu, M.Z. (2017). 8. sınıf öğrencilerinin üçgenler konusunda problem kurma çalışmalarının incelenmesi. Bayburt Eğitim Fakültesi Dergisi, 12(24), 467-486.

Ünlü, M., \& Sarpkaya-Aktaş, G. (2017). Ortaokul matematik öğretmeni adaylarının cebirsel ifade ve denklemlere yönelik kurdukları problemlerin incelenmesi. Turkish Journal of Computer and Mathematics Education, 8(1), 161-187. 
Weissglass, J. (2002). In focus... inequity in mathematics education: Questions for educators. The Mathematics Educator, 12(2), 34-39.

Yuan, X., \& Sriraman, B. (2011). An exploratory study of relationships between students' creativity and mathematical problem-posing abilities. In B. Sriraman \& K. Lee (Eds.), The elements of creativity and giftedness in mathematics (pp. 5-28). Rotterdam: Sense Publishers.

Zimmerman, B.J. (2000). Self-efficacy: An essential motive to learn. Contemporary Educational Psychology, 25(1), 82-91.

\section{Summary}

Problem solving, problem-posing and affective skills towards mathematics are among basic skills in mathematics education. Although it is frequently emphasized in the studies about mathematics education in recent years, there is little known about the problem-posing processes (Kilpatrick, 1987). Studies shows that problem-posing and problem-solving skills complement each other (Cai, 1998; Ellerton, 1986; Silver \& Cai, 1996). Furthermore, it is stated that problem-posing activities positively affected students' problem-solving skills (Cai et al., 2013). In this respect, it is thought that examining the problem-posing skills of middle school students will clarify this situation.

One of the main objectives of mathematics teaching is to develop students' affective skills in mathematics (MEB, 2013). One of these affective skills is students' self-efficacy beliefs. There are various studies about self-efficacy beliefs, individual's attitudes towards mathematics, mathematics achievement (Ayotola \& Adedeji, 2009; Hackett \& Betz, 1989; Pajares, 1996), problem-solving skills (Pajares \& Graham, 1999; Pajares \& Miller, 1994), problem-posing skills (Nicolau \& Philippou, 2007), mathematical anxiety (Bandura, 1997; Hoffman, 2010). There are limited studies investigating the self-efficacy of middle school students for problem-posing (Nicolaou \& Philippou, 2007).

The aim of this study is to determine problem-posing skills and problem-posing selfefficacy of middle school students. Also, the effects of independent variables as problem posing situation, gender, grade level and academic achievement were examined. The findings of this study are thought to provide valuable information about the problem-posing.

\section{Method}

This research is a quantitative study investigating problem-posing skills and problemposing efficacy of middle school students. The study employed descriptive survey research 
design. This research was carried out with 346 middle school students in four different schools in 2017-2018 academic years. Problem-posing test and problem-posing self-efficacy scale were used to collect data. Quantitative analyzes were used.

\section{Findings}

The problem-posing skills of the middle school students who participated in the research were at a good level. It was found that no participant could get the maximum score of 126 which can be taken from the problem-posing test. Although the mean scores of the participants from different grade levels from the problem-posing test were close to each other, it was determined that 7th grade students were more unsuccessful than the 6th and 8th grade students. 8th grade students were more successful than the 6th and 7 th grade students in the problem-posing test.

Although the average scores of middle school students in different problem-posing situations were considered to be close to each other, it was observed that the participants had the best results in free problem-posing situations and the lowest results in structured problemposing situations. This was the same for participants at all grade levels. In addition to this, it was found that 6 th grade students were more successful in free problem-posing situations while 8th grade students were more successful at structured problem-posing situations.

Analyzes showed that participants' problem posing skills did not differ according to their gender and class level but differed significantly according to their mathematic achievement.

Participants had high problem-posing self-efficacy beliefs. The self-efficacy beliefs of 6th grade students were higher than the 7th and 8th grade students. Analyzes showed that as the grade level increased efficacy beliefs of the participants decreased. Problem-posing selfefficacy beliefs of participants' did not differ according to their gender but differed significantly according to their grade level and mathematic achievement. It was also found that self-efficacy beliefs of participants were significant predictors of their problem-posing skills.

\section{Discussion and Conclusion}

This study showed participants had good results in problem-posing activities. Middle school students' problem-posing skills are related to their experience in problem solving, academic achievement, content information, content of activities, etc. While students can pose a problem related to a mathematics subject, they may not be able to pose a problem related for 
a different one. Since the problem-posing activities are open-ended (Kovacs, 2017), it can be concluded that different results can be obtained in different situations.

It can be expected that the problem-posing skills of middle school students will increase when their class levels increase, considering that they will think more abstract and have deeper content knowledge. However, this view may not always be confirmed, as the academic and social characteristics of participants at different grade levels may differ. It is thought that more accurate information about this subject can be obtained by future longitudinal researches.

Participants were more successful in free problem posing situations. Less limitations in free problem-setting may have made it easier for students to set up problems in these problemposing situations. In structured problem-posing situations, the limitations are as high as possible. Therefore, participants may have difficulty in establishing problems in these situations. Moreover, the difficulties of the participants of this research in semi-structured and structured problem-posing situations may be due to their lack of knowledge about problemposing strategies.

Analyzes showed that participants had high problem posing self-efficacy beliefs. The participants of this study were generally students with good academic achievement. Considering that there was a positive relationship between academic achievement and selfefficacy beliefs (Hackett \& Betz, 1989), this result was expectable.

Students should have more experience with problem-posing activities and contribute to their academic achievement levels. Middle school students should be educated on problemposing strategies so that they can be more successful in semi-structured and structured problemsetting situations, which may require knowledge of specific strategies. It is important for all students to gain experience in problem-posing and to have self-efficacy beliefs in these activities so that they can have high problem-posing skills and problem-posing self-efficacy beliefs. 